\title{
RSV Disease: Current Management and the Future of Treatment and Prevention
}

\author{
Leonard R. Krilov · Joseph B. Domachowske · Evan J. Anderson
}

Received: December 8, 2020 / Accepted: December 9, 2020 / Published online: March 3, 2021

(C) The Author(s) 2021

Keywords: American Academy of Pediatrics; Cost; Epidemiology; Prevention or Immunoprophylaxis; Palivizumab; Respiratory syncytial virus; Respiratory syncytial virus hospitalizations; Treatments

\section{DIGITAL FEATURES}

This article is published with digital features to facilitate understanding of the article. To view digital features for this article go to https://doi. org/10.6084/m9.figshare.13326047.

L. R. Krilov ( $₫)$

Department of Pediatrics, NYU Langone HospitalLong Island and the NYU Long Island School of Medicine, Mineola, NY, USA

e-mail: Leonard.Krilov@nyulangone.org

J. B. Domachowske

Department of Pediatrics, SUNY Upstate Medical

University, Syracuse, NY, USA

E. J. Anderson

Department of Pediatrics, Emory University School of Medicine, Atlanta, GA, USA

\section{E. J. Anderson}

Department of Medicine, Emory University School of Medicine, Atlanta, GA, USA

\section{EDITORIAL}

Since the initial discovery of respiratory syncytial virus (RSV) in 1956 and its association with infant bronchiolitis, much has been learned about the epidemiology and clinical manifestations of RSV infection [1, 2]. Despite these developments, effective treatments are lacking [3]. Immunoprophylaxis (IP) with the humanized monoclonal antibody palivizumab has been available since 1998 and is highly effective [reducing RSV hospitalization (RSVH) rates up to $78 \%$ and preventing RSVH by $58 \%$ in highrisk pediatric populations] [3-7]. However, due to cost concerns and controversy surrounding the optimal patient populations for such IP, its use is limited to high-risk infants and children [3].

Recent epidemiologic studies are helping to better define the severity and costs associated with RSV infection in high-risk patients $[8,9]$. These data will facilitate identifying the most appropriate populations to recommend for RSV IP. Additionally, antiviral treatments, vaccines, and a long-acting IP agent are on the horizon. Data supporting their use in late phase clinical trials are needed to demonstrate safety and efficacy [3].

In this compendium, experts in the field present updates on exciting developments. The supplement begins with an overview by Chatterjee et al. of the current state of RSV 
management and changes in the American Academy of Pediatrics (AAP) policy for RSV IP use since 1998. Goldstein et al. then discuss the impact of the 2014 AAP policy for RSV IP on RSVH in premature infants (born at 29-34 weeks' gestational age). This is followed by a further analysis of the severity and costs of RSVH among premature infants by Krilov et al. Young et al. address the socioeconomic impact of RSVH in high-risk populations and the potential of these observations to warrant a reassessment of the AAP policy for RSV IP use. Finally, Domachowske et al. describe exciting potential advances in RSV treatment and prevention, but caution that clinical implementation remains at least several years in the future.

On behalf of all the authors involved in the development of this supplement, we hope the readers find these updates informative. The advances in the understanding of RSV-related epidemiology and management options described in this supplement may translate to improved care and prevention of the substantial morbidity associated with RSV in infants and young children in the foreseeable future.

\section{ACKNOWLEDGEMENTS}

This supplement has been sponsored by Sobi, Inc. Robert C. Welliver served as the Guest Editor for this supplement and has the following disclosures: He has received funding from Novavax for preclinical work on their RSV vaccine in a maternal immunization study, funding from $\mathrm{AZ}$ for evaluation of nirsevimab, past funding from AstraZeneca for various RSV antibody studies, and from MedImmune before that. He has also received funding from Regeneron in the past for their RSV monoclonal antibody study. Finally, he is receiving NIAID (1 R41 A147787-01) funding for study of an RSV vaccine.

Funding. This study and the Rapid Service Fees were sponsored by Sobi, Inc.

Medical writing and editorial assistance. Writing and editorial support were provided by PRECISIONscientia, Inc., which were in accordance with Good Publication Practice (GPP3) guidelines and funded by Sobi, Inc.

Authorship. All named authors meet the International Committee of Medical Journal Editors (ICMJE) criteria for authorship for this article, take responsibility for the integrity of the work as a whole, and have given their approval for this version to be published.

Disclosures. Leonard R. Krilov has received grant and research support for clinical trials from AstraZeneca, Regeneron Pharmaceuticals, Pfizer, and Sanofi Pasteur. LRK has been a consultant to Pfizer. Joseph B. Domachowske's institution receives funds on his behalf to conduct clinical research from MedImmune, Regeneron Pharmaceuticals, Pfizer, GSK, Merck, Novavax, and Sanofi Pasteur. Evan J. Anderson has received personal fees from AbbVie and Pfizer for consulting, and his institution receives funds to conduct clinical research from MedImmune, Regeneron Pharmaceuticals, PaxVax Corporation, Pfizer, GSK, Merck, Novavax, Sanofi Pasteur, and Micron.

Compliance with ethics guidelines. This article is based on previously conducted studies and does not contain any studies with human participants or animals performed by any of the authors.

Open Access. This article is licensed under a Creative Commons Attribution-NonCommercial 4.0 International License, which permits any non-commercial use, sharing, adaptation, distribution and reproduction in any medium or format, as long as you give appropriate credit to the original author(s) and the source, provide a link to the Creative Commons licence, and indicate if changes were made. The images or other third party material in this article are included in the article's Creative Commons licence, unless indicated otherwise in a credit line to the material. If material is not included in the article's Creative Commons licence and your intended use is not permitted by statutory regulation or exceeds the permitted use, you 
will need to obtain permission directly from the copyright holder. To view a copy of this licence, visit http://creativecommons.org/licenses/by$\mathrm{nc} / 4.0 /$.

\section{REFERENCES}

1. Collins PL, Crowe JE Jr. Respiratory syncytial virus and metapneumovirus. In: Knipe DM, Howley PM, Griffin DE, et al., editors. Fields' virology, vol. 2. 5th ed. Philadelphia, PA: Lippincott Williams \& Wilkins; 2007. p. 1601-46.

2. Resch B. Product review on the monoclonal antibody palivizumab for prevention of respiratory syncytial virus infection. Hum Vaccin Immunother. 2017; 13(9):2138-49. https://doi.org/10.1080/21645515. 2017.1337614.

3. Simões EAF, Bont L, Manzoni P, et al. Past, present and future approaches to the prevention and treatment of respiratory syncytial virus infection in children. Infect Dis Ther. 2018;7(1):87-120. https://doi. org/10.1007/s40121-018-0188-z.

4. SYNAGIS [package insert]. Gaithersburg, MD: MedImmune, LLC; 2017.
5. The IMpact-RSV Study Group. Palivizumab, a humanized respiratory syncytial virus monoclonal antibody, reduces hospitalization from respiratory syncytial virus infection in high-risk infants. Pediatrics. 1998;102(3 Pt 1):531-7.

6. Feltes TF, Cabalka AK, Meissner HC, et al. Palivizumab prophylaxis reduces hospitalization due to respiratory syncytial virus in young children with hemodynamically significant congenital heart disease. J Pediatr. 2003;143(4):532-40.

7. Anderson EJ, Carosone-Link P, Yogev R, et al. Effectiveness of palivizumab in high-risk infants and children: a propensity score weighted regression analysis. Pediatr Infect Dis J. 2017;36(8):699-704. https://doi.org/10.1097/INF.0000000000001533.

8. Anderson EJ, DeVincenzo JP, Simões EAF, et al. SENTINEL1: Two-season study of respiratory syncytial virus hospitalizations among U.S. infants born at 29 to 35 weeks' gestational age not receiving immunoprophylaxis. Am J Perinatol. 2020;37(4):421-9. https://doi.org/10.1055/s-0039-1681014.

9. Díez-Domingo J, Pérez-Yarza EG, Melero JA, et al. Social, economic, and health impact of the respiratory syncytial virus: a systematic search. BMC Infect Dis. 2014;14:544. https://doi.org/10.1186/s12879014-0544-X. 